\title{
Silent Slaughter: How freedom of speech and expression restrictions keep animal abuses hidden and stifle animal welfare activism in Europe and the United States
}

\author{
Mahalia Kahsay \\ J.D. Candidate, University of Michigan, USA
}

Received: September 2019

Accepted: December 2019

Recommended citation. KAHSAY M., Silent slaughter: how freedom of speech and expression restrictions keep animal abuses hidden and stifle animal welfare activism in Europe and the United States, dA. Derecho Animal (Forum of Animal Law Studies) 10/1 (2019) - DOI https://doi.org/10.5565/rev/da.364

\begin{abstract}
Billions of animals worldwide are used annually for human consumption. The agricultural industry enjoys a high-level of state protection because of its role in supplying the populace with food, and in turn, supporting the nation's security. In Europe and the United States, activists make similar challenges to status quo animal industry practices: activists use video cameras to expose animal abuses and share their findings with the public. Several U.S. states with strong animal agricultural industries have passed "aggag" laws aimed at outlawing many of these activities, including filming undercover and entering slaughterhouses under false pretenses. Finding these laws restrict free speech and impede efforts to gather evidence for whistle blowing operations, activists have challenged these laws in U.S. federal district courts. This paper examines three of these lawsuits, including two in which activists won rather "easily" under favorable U.S. free speech jurisprudence. Next, I compare these cases to three free speech and expression cases brought by animal activists in Europe. I use this comparison to argue that even well written and strategically crafted "ag-gag" laws are unlikely to withstand judicial scrutiny in the future because U.S. free speech jurisprudence exists to protect against the very purpose of ag-gag laws: government-led silencing of speech at the request of a powerful industry group.
\end{abstract}

Keywords: First Amendment; freedom of expression; ag-gag.

Resumen - Matanza silenciosa: Cómo las restricciones en la libertad de opinión y de expresión mantienen escondidos los abusos a animales y reprimen el activismo por el bienestar animal en Europa y Estados Unidos.

Miles de millones de animales en todo el mundo se utilizan anualmente para el consumo humano. La industria agrícola goza de un alto nivel de protección estatal debido a su papel en el suministro de alimentos a la población y, a su vez, a la seguridad de la nación. En Europa y los Estados Unidos, los activistas hacen desafíos similares a las prácticas de la industria animal del status quo: usan cámaras de vídeo para exponer los abusos a los animales y compartir sus hallazgos con el público. Varios estados de EE.UU. con importantes industrias agrícolas y ganaderas han aprobado leyes "ag-gag" destinadas a prohibir muchas de estas actividades, incluida la filmación de instalaciones y la entrada a mataderos con falsos pretextos. Al encontrar que estas leyes restringen la libertad de expresión y obstaculizan los esfuerzos para reunir pruebas que permitan denunciar, los activistas han cuestionado estas leyes en los tribunales de los distritos federales de los Estados Unidos. Este documento examina tres de estas demandas, incluidas dos en las que los activistas ganaron bastante "fácilmente" bajo la favorable jurisprudencia de la libertad de expresión de los EE.UU. A continuación, comparo estos casos con tres casos de libertad de opinión y expresión presentados por animalistas en Europa. Utilizo esta comparación para argumentar que es improbable que incluso las leyes "ag-gag" bien redactadas y elaboradas estratégicamente resistan el escrutinio judicial en el futuro 
porque la jurisprudencia de la libertad de expresión de los EE.UU. existe como medida de protección contra cada uno de los propósitos de las leyes "ag-gag": el silenciamiento del discurso dirigido por el gobierno a petición de un poderoso grupo industrial.

Palabras clave: Primera Enmienda; libertad de expresión; ag-gag.

\section{BACKGROUND}

\section{INTRODUCTION}

The agricultural use of animals accounts for the slaughter of over 60 billion land animals annually worldwide. ${ }^{1}$ A dramatic increase in animal production in the U.S. parallels a worldwide trend towards mass production. In the U.S. for example, for every one egg producer today, twenty egg producers worked four decades ago; the number of pig farmers declined by ninety-nine percent in the same period. ${ }^{2}$ Presently in China people consume four times as much meat as a few decades ago, while livestock drink over half of all consumed water. ${ }^{3}$ China and the U.S. alone are not to blame; the average consumer in an industrialized country eats over 180 pounds of meat, 450 pounds of dairy, and twenty-five pounds of eggs per year. ${ }^{4}$

To keep up with demand, mass production - fueled by efficiency-is skyrocketing. Crowded conditions, increased automation, a single species per warehouse - these conditions characterize the industrial systems that today produce over half of the world's pork and over two-thirds of its poultry, meat and eggs. ${ }^{5}$ These agricultural operations provide harsh environments and crowded conditions. For example, both meat and egg chickens have personal space the size of a single sheet of paper; pregnant pigs sit confined so tightly they cannot walk one step. ${ }^{6}$

Some consumers can recall horror stories of grotesque animal abuse exposed by investigative news reports or animal welfare organizations. Through the investigative work of animal activists and the Internet, consumers have newfound access to animal abuse findings. Shifts in public opinion within the past two decades ${ }^{7}$ point strongly to increased concern for the welfare of agricultural animals, leading directly to bans on battery cages for hens and regulations to improve conditions for pregnant pigs in the European Union and a few U.S. states. ${ }^{8}$

The public cannot support agricultural animal welfare reforms without information about the state of animal welfare inside agricultural operations. Unsurprisingly, an increase in public interest has been met with resistance from the agricultural industry, especially in the United States. Under the guise of protecting private property and the food industry, the U.S. federal government passed an anti-terrorism act targeting animal rights activists. Many states went one step further, criminalizing photography or video filming inside animal agricultural operations without the consent of the owner. These laws are commonly referred to as "ag-gag laws."

In Europe, attempts to expose abuses inside animal operations meet a different challenge: videos exposing animal welfare conditions are blocked from broadcast on television and general dissemination. Under Article 10 of the European Convention on Human Rights, all individuals under the jurisdiction of any Council of Europe member state have "the right to freedom of expression," notwithstanding certain exceptions. Animal activists in Europe challenge applicable member state criminal and civil code regulations as illegal restrictions on their right to freedom of expression. The European Court of Human Rights adjudicates these claims, weighing the function of the expression, the penalty, and whether the

\footnotetext{
${ }^{1}$ STUCKI, S., (Certified) Humane Violence? Animal Welfare Labels, the Ambivalence of Humanizing the Inhumane, and What International Humanitarian Law Has to Do with It, AJIL Unbound 111 (2017) 277 (https://doi.org/10.1017/aju.2017.65); PARK, M., SINGER, P., The Globalization of Animal Welfare: More Food Does Not Require More Suffering, Foreign Affairs, Mar./Apr. (2012) 122.

${ }^{2}$ SINGER, P., Open the Cages!, The New York Review of Books (May 12, 2016), reviewing PACELLE, W., The Humane Economy: How Innovators And Enlightened Consumers Are Transforming The Lives Of Animals (2016), http://www.nybooks.com/articles/2016/05/12/humane-economy-open-the-cages/ [Accessed 12 Dec. 2017].

${ }^{3}$ SAFRAN FOER, J., Eating Animals (New York 2009) 262.

${ }^{4}$ PARK, M., SINGER, P., supra note 1, at 124.

${ }^{5} \mathrm{Id}$. at 126 .

${ }^{6} I d$.

${ }^{7}$ PARK, M., SINGER, P., supra note 1, at 129.

${ }^{8}$ Id. 126; SingER, P., supra note 2, at 7; Council Directive 2008/120, of Dec. 18, 2008 Laying down minimum standards for the protection of pigs, 2008 O.J. (L 47) (EC); Council Directive 1999/74, of July 19, 1999, Laying down minimum standards for the protection of laying hens, 1999 O.J. (L 203) (EC).
} 
expression is a fact or value judgement against member states' duty to protect democracy, speech, privacy, and safety. ${ }^{9}$

This paper examines three recent cases that challenged U.S. state "ag-gag" laws that restricted access to and speech in agricultural operations. Next, I compare these challenges to free speech and expression challenges brought by European activists to the European Court of Human Rights, comparing the process and rationale these courts use when examining speech and expression restrictions. Finally, I offer possible procedural, historical, and contextual reasons for differences in outcomes between Europe and the U.S. In conclusion, I suggest that while present day poorly written U.S. "ag-gag" laws are easily challengeable, the strict scrutiny jurisprudence of the First Amendment is well-adept to handle any attempt by legislators to pass more strategically crafted ag-gag laws in the future.

\section{THE FREE SPEECH REGIME IN THE UNITED STATES}

Individual rights have played a central role in U.S. constitutional culture since U.S. independence. ${ }^{10} \mathrm{~A}$ lack of explicit free speech protections in the U.S. Constitution pushed many framers to advocate for the inclusion of a freedom of speech clause in the Bill of Rights. ${ }^{11}$ Thomas Jefferson warned against the "tyranny of the legislatures" 12 and many scholars believe the First Amendment sought to limit speech restricting laws, like those from England prohibiting "seditious libel" to punish dissent in the colonies, on future U.S. soil. ${ }^{13}$

These concerns led Congress to word the First Amendment as an explicit limit on the federal government. ${ }^{14}$ Rather than frame the freedom of speech as a positive individual right, a limit commences the Bill of Rights. The text of the First Amendment of the U.S. Constitution guarantees:

Congress shall make no law respecting an establishment of religion, or prohibiting the free exercise thereof; or abridging the freedom of speech, or of the press; or the right of the people peaceably to assemble, and to petition the government for a redress of grievances. ${ }^{15}$

As a result, the right to free speech is worded as a direct limitation on the government. Justice Brennan, an Associate Justice of the United States Supreme Court famously said that in the U.S. exists a "profound national commitment to the principle that debate on public issues should be uninhibited, robust, and wide-open." 16 His famous statement clarifies that this commitment goes so far as to include "...vehement, caustic, and sometimes unpleasantly sharp attacks on government and public officials." ${ }^{17}$ As a result, speech is special, well-loved, and vehemently protected.

Despite these broad protections, the U.S. Supreme Court has long held that the First Amendment "does not confer an absolute right to speak... whatever one may choose." ${ }^{18}$ The core of the First Amendment forbids the government's regulation of speech based on its content or message. ${ }^{19}$ A content-based limitation imposes a legal restriction dependent on the words said, whereas a content-neutral restriction limits speech based on the time, place, or manner of speech. ${ }^{20}$ Thus, U.S. courts apply a formal categorical approach; once the right to free speech is implicated, it weighs heavily. ${ }^{21}$ Additionally, legal scholar Halberstam argues the dominant conception of rights in the United States is a "motivational one." 22 Under this view, rights involve freedom from government intervention "motivated by a particular set of excluded reasons." 23 As a result, the

\footnotetext{
${ }^{9}$ RANEY B. et al. eds., Jacobs, White \& Ovey: The European Convention on Human Rights, 17 (Oxford Univ. Press 2017 ) 484.

${ }^{10}$ TUSHNET, M., The Constitution Of The United States Of America: A Contextual Analysis (Oxford: Hart Publishing 2015) 187, noting the very first amendments to the U.S. Constitution were explicitly "described as a Bill of Rights".

${ }^{11}$ ABRAMS, F., The Soul Of The First Amendment (Yale Univ. Press 2017) 6.

12 HABER, T. I. \& EMERSON, D., Political And Civil Rights In The United States: A Collection Of Legal And Related Materials (Dennis \& Co., 2nd ed. 1952) 4.

${ }^{13}$ CHEMERINSKY, E., Constitutional Law, Principles, And Policies (Wolters Kluwer $5^{\text {th }}$ ed. 2015) 968, clarifying, however, that many of the Constitution's drafters helped adopt the Alien and Sedition Acts of 1798 to punish "false, scandalous, and malicious writing or writings against the government of the United States...".

${ }^{14}$ Id. 9 .

${ }^{15}$ U.S. CONST. amend. I.

${ }^{16}$ New York Times Co. v. Sullivan, 376 U.S. 254, 270 (U.S. 1964).

${ }^{17} \mathrm{Id}$.

${ }^{18}$ Gitlow v. New York, 268 U.S. 652, 666 (U.S. 1925).

${ }^{19}$ CHEMERINSKY, E., supra note 13, at 976.

${ }^{20}$ EPSTEIN, R. A., The Fundamentals of Freedom of Speech, Harvard Journal of Law and Public Policy, 10 (1987) 53.

${ }^{21}$ HALBERSTAM, D., Desperately Seeking Europe: On Comparative Methodology and the Conception of Rights, 5 International Journal of Constitutional Law, 5/1 (2007) 168.

${ }^{22} \mathrm{Id}$. at 78 .

${ }^{23} I d$.

146 Derecho Animal. Forum of Animal Law Studies, vol. 10/1
} 
right to free speech is not absolute, but simply the right to speak without government interference "for bad reasons." 24

Accordingly, U.S. Supreme Court calls for the strictest scrutiny for restrictions that "suppress, disadvantage, or impose differential burdens upon speech because its content." 25 Simply because the court finds a content-based restriction, however, does not automatically render the restriction unconstitutional. Rather, the government may justify the restriction as necessary to avoid undesirable consequences of the speech. ${ }^{26}$ Therefore, state government restrictions that prohibit or limit speech, while authorizing criminal punishments for violations, must pass a strict scrutiny test. ${ }^{27}$

The U.S. Supreme Court affirms the need to maintain open and free political discussion to ensure the government can respond to the peoples' will. ${ }^{28}$ "Silence coerced by law," the court declared, is "the argument of force in its worst form." ${ }^{29}$ As a result of these competing interests, the U.S. Supreme Court has developed complex jurisprudence balancing government interests and speech protections.

\section{a. A Brief History of Animal Rights Activism in the United States}

Undercover investigations in slaughterhouses and animal facilities in the U.S. have an infamous history. In the early $20^{\text {th }}$ Century, Upton Sinclair's exposé of Chicago's meatpacking industry in The Jungle produced public outcry and prompted Congress to regulate animal products and slaughterhouse conditions. ${ }^{30}$ Beginning in the 1990s, animal rights groups like Mercy for Animals, People for the Ethical Treatment of Animals ("PETA"), and the Animal Legal Defense Fund ("ALDF"), aided by new camera technology, began posing as employees to conduct undercover investigations in animal facilities. ${ }^{31}$ These groups conducted over 100 investigations in the last fifteen years alone, collecting hours of graphic footage. ${ }^{32}$

The video footage shocked viewers. ${ }^{33}$ Recordings showed workers dragging sick cows on cement floors, beating pigs with sledgehammers, and stomping chickens to death. ${ }^{34}$ Public outrage swiftly led to serious consequences. In 2012, a meat-packing company in California bankrupted and McDonalds refused to buy pork from producers who used gestation crates. ${ }^{35}$

\section{b. Ag-gag Laws in the United States: Silencing the Opposition}

The footage obtained through these investigations not only outraged consumers, but also producers. Panicked industry leaders rushed to their state legislatures for help in stopping what they compared to "terrorism... used by enemies for centuries to destroy the ability to produce food and the confidence in the food's safety." ${ }^{36}$ In 1990, Kansas became the first state to criminalize investigatory acts inside animal facilities: anyone who entered the facility "to take pictures by photograph, video camera, or by any other means... without the effective consent of the owner and with the intent to damage the enterprise..." faced a class A nonperson misdemeanor. ${ }^{37}$ Since 1990, eight states passed similar civil or criminal legislation.

A statute passed in Utah in 2012 criminalized "obtaining access to an agricultural operation under false pretenses" as a class B misdemeanor. ${ }^{38}$ In North Dakota, a law passed in 1991 allowed persons damaged by video recordings inside animal facilities to file a civil suit "to recover an amount equal to three times all actual and consequential damages." 39 Arkansas, Iowa, Missouri, and Montana all passed similar laws over the last two and a half decades. ${ }^{40}$ Together, these statutes effectively banned investigatory

\footnotetext{
${ }^{24} I d$.

${ }^{25}$ CHEMERINSKY, E., supra note 13, 977, quoting Turner Broad. Sys. v. FCC, 512 U.S. 622, 641 (U.S. 1994).

${ }^{26} I d$. at 983 , explaining that such a justification also requires the consequences be uniquely connected to the suppressed speech, and not also a consequence of the allowed free speech.

${ }^{27} \mathrm{Id}$. at 1015 .

${ }^{28}$ New York Times, 376 U.S. 254, at 269, citing Stromberg v. California, 283 U.S. 359, 369 (U.S. 1931).

${ }^{29} \mathrm{Id}$. at 283.

${ }^{30}$ GENOWAYS, T., Close to the Bone: The Fight Over Transparency in the Meat Industry, New York Times Magazine, Oct. 5, 2016.

${ }^{31}$ BERRY, Staff Attorney, Animal Legal Defense Fund, Guest Speaker at the University of Michigan's Student Animal Legal Defense Fund Lunch Talk on Ag-Gag Law (Nov. 2, 2017).

${ }^{32} I d$.

${ }^{33} I d$.

${ }^{34}$ New York Times Editorial Board, No More Exposés in North Carolina, The New York Times, Feb. 1, 2016.

${ }^{35}$ BERRY, supra note 31; see also GENOWAYS, supra note 30.

${ }^{36}$ Animal Legal Defense Fund v. Otter, 118 F.Supp.3d 1195, 1200 (D. Idaho 2015).

${ }^{37}$ KAN ANN. STAT. § 47-1827 (2017).

${ }^{38}$ UTAH CODE ANN. $\S \S 76-6-112$ (2017).

${ }^{39}$ N.D. CENT. CODE $\S \S 12.1-21.1-01,12.1-21.1-05$ (2017).

${ }^{40}$ Animal Legal Defense Fund, Taking Ag-Gag to Court, http://aldf.org/cases-campaigns/features/taking-ag-gag-to-court [Accessed
} 
activities by criminalizing unauthorized entry, entry by misrepresentation, film or photography inside facilities, and interference with animal production. ${ }^{41}$

\section{FREEDOM OF EXPRESSION IN THE EUROPEAN HUMAN RIGHTS REGIME}

The Council of Europe ("Council") self-identifies as Europe's leading human rights organization. ${ }^{42}$ Founded on May 5, 1949 to promote democracy, the Council currently boasts forty-seven member states, including all twenty-eight EU member states. ${ }^{43}$ Operating independently from the EU, the Council focuses on human rights, rule of law, and democracy work. Most importantly, Council member states created and ratified the Convention for the Protection of Human Rights and Fundamental Freedoms, commonly known as the European Convention on Human Rights ("Convention"). ${ }^{44}$

\section{a. The Object and Purpose of the European Convention on Human Rights}

The Convention entered into force in $1953 .{ }^{45}$ Inspired by the Universal Declaration of Human Rights, the Convention aimed to achieve unity, prevent a second Holocaust atrocity, and protect states from communism. ${ }^{46}$ As a result, drafters focused on rights within "the sphere of freedom of the individual vis-ávis the [g]overnment," whose implementation established a duty of governments to refrain from interfering with their exercise. ${ }^{47}$ The Convention's Preamble ${ }^{48}$ recognizes the delicate balance between the democratic nature of member state governance, and common observance of human rights in the Convention. It affirms the "like-mindedness" of European nations, whose shared tradition allows them to work together "for the collective enforcement" of the rights." 49 Such collective enforcement requires broad application; all member states must secure to all individuals in their territorial jurisdiction, residents and non-residents alike, the rights and freedoms guaranteed under the Convention. ${ }^{50}$

To ensure member states' compliance, the Convention established the permanent European Court of Human Rights ("Court"). ${ }^{51}$ The Court's jurisdiction applies to "all matters concerning the interpretation and application of the Convention" and subsequent protocols. ${ }^{52}$ Final judgments by the Court bind member states; the Committee of Ministers supervise their execution. ${ }^{53}$ Importantly, non-compliant states may be brought back to the Court for failing to implement a judgment. ${ }^{54}$

\section{a. Freedom Of Expression Under the European Convention on Human Rights}

The Convention protects the "right to freedom of expression" under Article 10:

Everyone has a right to freedom of expression. This right shall include freedom to hold opinions and to receive and impart information and ideas without interference by public authority and regardless of frontiers... ${ }^{55}$

\footnotetext{
26 Dec. 2017].

${ }^{41}$ See N.D. Cent. Code $\S \S 12.1-21.1-01,12.1-21.1-05$ (2017); UtAH Code ANN. §§ 76-6-112 (2017); KAN ANN. STAT. § 47-1827 (2017).

${ }^{42}$ Council of Europe, https://www.coe.int/en/web/about-us/who-we-are [Accessed 12 Dec. 2017].

${ }^{43}$ Our Member States, https://www.coe.int/en/web/about-us/who-we-are [Accessed 21 May 2017].

${ }^{44}$ European Convention on Human Rights, Nov. 4, 1950 (entered into force Sept. 3, 1953).

45 The European Court of Human Rights, http://www.echr.coe.int/pages/home.aspx?p=basictexts [Accessed 12 Dec. 2017 ].

${ }^{46}$ RAINEY, B. et. al., supra note 9, at 3-4.

${ }^{47}$ VAN DIJK, R., et al. eds., Theory and Practice of the European Convention on Human Rights (Intersentia: Antwerpen - Oxford $4^{\text {th }}$ ed. 2006) 6.

${ }^{48}$ European Convention on Human Rights, pmbl (broadly affirming the drafting parties and subsequent member states' belief in "those fundamental freedoms which are the foundation of justice and peace in the world and are best maintained on the one hand by an effective political democracy and on the other by a common understanding and the observance of the Human Rights upon which they depend").

${ }^{49} I d$.

${ }^{50}$ RAINEY, B. et. al., supra note 9, at 6, 17; See also Section 1 of the European Convention on Human Rights, arts. 1-18.

${ }^{51}$ Id. art. 19 "Establishment of the Court"; See also RAINEY, B. et. al., supra note 9, 17 (having the largest territorial jurisdiction in the world, the Court covers over 47 member states and over 800 million people).

${ }^{52}$ European Convention on Human Rights, art 32

${ }^{53}$ European Convention on Human Rights, art 46; RAINEY, B. et. al., supra note 9, at 5.

${ }^{54}$ See Case of Verein Gegen Tierfabriken Schweiz (VgT) v. Switzerland, No. 32772/02, Eur. Ct. H.R. (June 30, 2009), holding that Switzerland "failed to comply with their positive obligation under Article 10" after the Swiss Federal Court failed to order the commercial's broadcast after the Court's initial judgment.

${ }^{55}$ European Convention on Human Rights, art. $10 \S 1$.
}

148 Derecho Animal. Forum of Animal Law Studies, vol. 10/1 
The freedom of expression protects both the content of the expression and the communication itself, covering anyone involved in the making of the protected communication. ${ }^{56}$ While the text of Article 10 protects opinion expression, the Court's caselaw unconditionally protects the communication of facts, even if the facts turn out not to be true. ${ }^{57}$ As a result, many forms of expression, including books, film, videorecordings, information pamphlets, and the internet, are protected. ${ }^{58}$ Because the Convention allows states to limit expression via restrictions "prescribed by law" and "necessary in a democratic society," 59 questions of necessity and proportionality underlie the Court's assessment of states' domestic restrictions.

\section{b. Analyzing Member State Violations Under Article 10 of the Convention}

The European Court of Human Right's case law affirms the special role "freedom of expression" plays in both in protecting democracy and other Convention rights. ${ }^{60}$ With these purposes in mind, the Court developed principles to ascertain whether member state restrictions on the freedom of expression are permissible under the restrictions clause of Article $10 .{ }^{61}$ In addition to the requirement that each restriction be "prescribed by law," "necessary in a democratic society," and satisfy one of the listed interests, the Court requires they be strictly construed and convincingly established. ${ }^{62}$ Such construction "implies the existence of a 'pressing social need."'63

When examining a restriction, the Court assesses the proportionality of the restriction to the alleged pressing social need with the whole case in mind, balancing the restriction and "the legitimate aims pursued" in their proper contexts. ${ }^{64}$ In applying a margin of appreciation and recognizing that "the essence of democracy [requires] diverse political programmes to be proposed and debated..." ${ }^{65}$ the Court acknowledges member state diversity. But, the deference granted to member states has its limits. For example, the Court has held "there is little scope under Article $10 \S 2$ for restrictions on debates on questions of public interest." ${ }^{66}$ Finally, even a necessary, pressing, and legitimate interference must be construed strictly and established convincingly, in particular "when the nature of the speech is political rather than commercial." ${ }^{67}$

\section{c. Freedom of Expression for Animal Rights Activists and Organizations}

In the following cases, the Court specifically assessed restrictions which allegedly violated Article 10 by suppressing activists' ability to express pro-animal views. These cases highlight how the Court assesses whether the government sponsored restriction, prescribed by law, can withstand scrutiny as a legitimate exception under section 2 of Article 10. In this way, the Court's analysis follows the object and purpose of the Convention itself, balancing the need for member states to manage an effective political democracy against the Convention's aim to protect the very human rights on which member state democracies depend. ${ }^{68}$

\section{ANIMAL OPERATIONS IN THE UNITED STATES}

U.S. federal law defines animal agricultural operations to include "the production and marketing of agricultural commodities and livestock." ${ }^{69}$ The federal definition of agricultural product includes "any agricultural commodity or product, whether raw or processed, including any derived from livestock that is

\footnotetext{
${ }^{56}$ GRABENWARTER, C., European Convention on Human Rights Commentary (C.H. Beck 2014) 253.

${ }^{57} \mathrm{Id}$.

${ }^{58}$ RAINEY, B. et. al., supra note 9, at 484.

${ }^{59}$ European Convention on Human Rights, art. 10.

${ }^{60}$ RAINEY, B. et. al., supra note 9, at 486.

61 European Convention on Human Rights, art. $10 \S 2$ : "The exercise of these freedoms, since it carries with it duties and responsibilities, may be subject to such formalities, conditions, restrictions or penalties as are prescribed by law and are necessary in a democratic society, in the interests of national security, territorial integrity or public safety, for the prevention of disorder or crime, for the protection of health or morals, for the disclosure of information received in confidence, or for maintaining the authority and impartiality of the judiciary."

62 VAN DIJK, P. et al., supra note 47, at 774.

${ }^{63}$ GRABENWARTER, C., supra note 56, at 262.

${ }^{64}$ VAN DiJK, P. et al., supra note 47 , at 775.

${ }^{65}$ Case of Centro Europa 7 S.R.L. \& Di Stefano v. Italy, Eur. Ct. H.R. 1129 (June 7, 2012).

${ }^{66}$ Animal Def. Int'l, Eur. Ct. H.R. \ 102 (citing Wingrove v. The United Kingdom, Eur. Ct. H.R. ๆ 58 (Nov. 25, 1996).

${ }^{67}$ Vgt Verein Gegen Tierfabriken, Eur. Ct. H.R. \ 66.

${ }^{68}$ See European Convention on Human Rights, pmbl.

${ }^{69}$ Information Gathering, 7 U.S.C. § 8791(b)(1) (2017).
} 
marketed in the United State for human or livestock consumption."70 These agricultural products—cows, pigs, and chickens - used in animal agricultural operations in the United States lack legal protections under federal law. ${ }^{71}$ U.S. federal law defines animal agricultural operations to include "the production and marketing of agricultural commodities and livestock;"72 agricultural products include commodities "whether raw or processed...derived from livestock that is marketed in the U.S. for human or livestock consumption." 73

Agricultural animals fare no better under state law, as many exempt "livestock," "production animals," or "poultry" from their animal cruelty statutes. ${ }^{74}$ As a result, the public must voice their animal welfare concerns with its wallet. If treating animals humanely becomes economically profitable, industries will respond accordingly. Unfortunately, consumers wield little power in the animal agriculture industry because several obstacles prevent consumers from making informed decisions.

The first obstacle, a lack of federal and state protections welfare protections for agriculture animals, leaves consumers without regulated humane alternatives. The second obstacle is a lack of information: consumers must rely on whistleblower information about animal cruelty because agricultural operations do not share videos or information about their activities. This reliance on whistleblowers makes the new wave of so called "ag-gag laws"- laws criminalizing many undercover investigation activities in industrial animal agricultural operations - all the more devastating. State governments' active support of the animal agriculture industry threatens consumers' access to information. When legislators respond to industry fears of exposure by reducing transparency, consumers and animals lose.

\section{a. Federal Protections for Agricultural Animals in the United States}

Few federal statutes address animal welfare. The Animal Welfare Act of 1966 ("Welfare Act") and subsequent amendments regulate the sale, handling, and transport of dogs, cats, and research animals; later amendments regulate dog fighting and pet stores. ${ }^{75}$ The Welfare Act explicitly excludes agricultural animals. ${ }^{76}$ The Humane Slaughter Act of 1958 attempted to create a baseline standard for all animal slaughter in the U.S. The Humane Slaughter Act mandates that "no method of slaughtering or handling in connection with slaughtering shall be deemed to comply with the public policy of the U.S. unless it is humane." 77 It defines two slaughter methods as humane: one requires certain livestock be "rendered insensible to pain" before being "thrown, cast or cut," $" 78$ while the other grants a religious exception to any faith slaughtering via "simultaneous and instantaneous severance of the carotid arteries with a sharp instrument." 79 Importantly, any requirements for humane treatment throughout the animal's life are absent.

\section{b. Federal Government Support of the Animal Agriculture Industry in the United States: Are Animal Activists Terrorists?}

Decades of federal government support of the animal agricultural industry in the U.S. reached an apex in 2006 with the passage of the Animal Enterprise Terrorism Act ("Terrorism Act"). ${ }^{80}$ The Terrorism Act subjects anyone who travels in interstate commerce with "the purpose of damaging or interfering with the operations of an animal enterprise... and causes the loss of any real or personal property... [or] conspires or attempts to do so" to varying prison sentences, fines, and restitution payments. ${ }^{81}$ By labeling any activities that interfere with animal enterprises ${ }^{82}$ or operations as terrorism, the Terrorism Act harshly punishes many

\footnotetext{
70 Food, Conservation, and Trade Act of 1990 § 2103 (1) Reporter 104 Stat. 3359.

${ }^{71}$ See Animal Welfare Act of 1970, 91 P.L. 579 (1970); See also Dogs, Cats, and Other Animals: Research or Experimental Use, 89 P.L. 544 (1966).

72 Information Gathering, 7 U.S.C. § 8791(b)(1) (2017).

${ }^{73}$ Food, Conservation, and Trade Act of 1990 § 2103 (1) Reporter 104 Stat. 3359.

${ }^{74}$ E.g., UTAH CODE ANN. § 76-9-301(b)(ii)(C) (2017) defining "animal" to exclude "livestock, if... the conduct toward the creature, and the care provided to the creature, is in accordance with accepted animal husbandry practices." Such accepted animal husbandry practices are not further defined; $C f$. IDAHO CODE $\S 25-3501 \mathrm{~A}(3)(2)(\mathrm{b})$ (forbidding law enforcement from removing a production animal despite a violation without first obtaining written permission from a department investigator); See also Mo. REV. STAT. $\S$ 578.182(1)(3) and FLA. STAT. § 828.125(5).

${ }^{75}$ Animal Welfare Act of 1970, 91 P.L. 579 (1970).

767 U.S.C. $\S 2132$ (g) (2017) by defining the term "animal" to exclude "other farm animals, such as, but not limited to livestock or poultry," the act does not cover any agricultural production animals.

${ }_{77}$ Humane Methods, 7 U.S.C. $\$ 1902$ (2017).

${ }^{78}$ Id. $\S 1902(\mathrm{a})$.

${ }^{79} I d . \S 1902(\mathrm{~b})$.

${ }^{80}$ Animal Enterprise Terrorism Act, 109 P.L. 374, codified as amended at 42 U.S.C. $\S 43$ (2006).

${ }^{81} I d$. $\S 43(\mathrm{a})(1)-2(\mathrm{~A})$.

${ }^{82}$ The term "animal enterprise" as used in the Animal Enterprise Terrorism Act encompasses the agricultural operations as defined 150 Derecho Animal. Forum of Animal Law Studies, vol. 10/1
} 
activities already illegal under federal and state law only because of their relation to animal enterprises. ${ }^{83}$

The Terrorism Act is a fearful government response to growing success by animal activist groups. Beginning in the 1990s, activists in the U.S. helped pass several animal welfare reform laws, including hunting bans in California and Colorado. ${ }^{84}$ Other activists pursued non-legislative strategies including civil disobedience, sabotage, and direct attacks on animal facilities. ${ }^{85}$ The federal government responded swiftly to calls from the animal agricultural industry to stop these activities with the Terrorism Act. States soon followed suit.

\section{CASE LAW ANALYSIS}

\section{CHALLENGES TO AG-GAG LAWS IN THE UNITED STATES}

Beginning in the early 1990s, states passed sweeping legislation criminalizing activities commonly used by animal welfare groups to expose animal cruelty in slaughterhouses and production facilities. ${ }^{86}$ While the Terrorism Act clarifies that it should not be construed "to prohibit any expressive conduct... protected from legal prohibition by the First Amendment," 87 state laws lacked similar protections. Unsurprisingly, challenges to these laws focus on the First Amendment.

\section{a. Alleging Actual Injuries and Standing to Challenge: People for the Ethical Treatment of Animals v. Stein.}

In May 2017, a federal district court in North Carolina dismissed a First Amendment challenge brought by PETA and seven other organizations, including ALDF, against North Carolina's Attorney General and the University of North Carolina at Chapel Hill ("UNC"), for failure to show that they had suffered any real injury; thus, they lacked standing to bring a case against the state in the first place. ${ }^{88}$ On June 5, 2018, the Fourth Circuit Court of Appeals reversed in an unpublished opinion, holding the district court erred in dismissing the claim. ${ }^{89}$

The case began when PETA challenged the constitutionality of North Carolina's 2015 Property Protection Act ("Act"), which allowed animal facility operators to recover up to $\$ 5,000$ per day in exemplary damages for "an act that exceeds a person's authority to enter the non-public areas of another's premises." ${ }^{90}$ Qualifying acts included entering nonpublic areas for purposes other than doing business, as well as placing an unattended surveillance device to record inside the facility. ${ }^{91}$

From 2001 to 2003, PETA discovered and publicized conduct involving lab animals in non-public laboratories at UNC. ${ }^{92}$ PETA planned to conduct similar investigations in the future and ALDF spent thousands of dollars on advertisements to recruit more investigators. ${ }^{93}$ Together, they alleged the Act prevented them from conducting investigations without fear of being sued for damages (fear of liability), and prevented them from receiving information obtained through the film footage (receipt of speech). ${ }^{94}$

PETA alleged the law facially violated the First Amendment "because it constitute[d] a content-based restriction on speech and cannot pass strict scrutiny," and sought an injunction against its enforcement. ${ }^{95}$ The district court held they failed to demonstrate standing to bring their claims. ${ }^{96}$ In order to demonstrate standing, plaintiffs must show first either an injury-in-fact or threatened injury; ${ }^{97}$ the court found Plaintiffs'

in the previous paragraphs and as discussed in this paper, see 18 U.S.C. $\S 43$ Force, violence, and threats involving animal enterprises, at $\S(d)(1)(A)$ Definitions (defining animal enterprises as "a commercial or academic enterprise that uses or sells animals or animal products for profit, food or fiber production, agriculture, education, research, or testing").

${ }^{83}$ STUPPLE, A. T., Terrorism and the Animal Rights And Environmental Movements, Journal of Animal and Natural Resource Law, 11 (2015) 51.

${ }^{84}$ PACELLE, W., The Long Road to Animal Welfare: How Activism Works in Practice, Foreign Affairs, (July/Aug. 2015$) 71$.

${ }^{85}$ STUPPLE, A.T., supra note 83, at 61.

${ }^{86}$ Animal Legal Defense Fund, Taking Ag-Gag to Court, http://aldf.org/cases-campaigns/features/taking-ag-gag-to-court/ [Accessed 26 Dec. 2017].

${ }^{87}$ Animal Enterprise Terrorism Act, 109 P.L. 374 (codified as amended at 42 U.S.C. $§ 43(e)(1)$ (2006).

${ }^{88}$ People for the Ethical Treatment of Animals v. Stein, 259 F. Supp.3d 369, 372 (M.D.N.C. 2017).

${ }^{89}$ People for the Ethical Treatment of Animals v. Stein, 2018 WL 2714684, *1 (4th Cir. June 5, 2018).

${ }^{90}$ N.C. Gen. STAT. § 99A-2 (2017).

${ }^{91} I d$.

${ }^{92}$ PETA, 259 F. Supp.3d, 373.

${ }^{93}$ Id.

${ }^{94}$ PETA, 259 F. Supp.3d, 376.

${ }^{95} \mathrm{Id}$. at 374 .

${ }^{96} I d$. at 375,386 .

${ }^{97} I d$. at 375; see also Id. at 375, quoting Beck v. McDonald, 848 F.3d 262, 269 (4th Cir. 2017) requiring for an injury-in-fact "a 
claimed injuries of fear of liability or blocked receipt of speech insufficient. ${ }^{98}$ UNC had not yet acted-it was "purely speculative whether Defendants - or anyone else - will engage in the complained-of conduct of invoking the [law] against any Plaintiff." 99 As for the receipt of speech, the court found Plaintiffs "fail[ed] to allege that most of the information they seek actually exists at all;" additionally, the Act did not prevent Plaintiffs from discovering this information because it only prevented recording. ${ }^{100}$

The Fourth Circuit Court of Appeals reversed the lower court's decision. ${ }^{101}$ The Court emphasized PETA and ALDF's long and successful tradition of using uncover investigations to fulfill their missions as a reason to believe the legislation targeted them specifically. ${ }^{102}$ The Court also explained the relaxed standing requirement in First Amendment cases. ${ }^{103}$ To satisfy the injury-in-fact requirement, plaintiffs can simply show the challenged statute has "an objectively reasonable chilling effect" on their exercise of free speech. ${ }^{104}$ Because the Court found a credible threat of the ag-gag law's enforcement against the plaintiffs, they sufficiently demonstrated an injury-in-fact and have standing to bring a claim under the First Amendment. ${ }^{105}$ Further proceedings consistent with the Fourth Circuit's decision are pending.

\section{b. Speech Restrictions Aimed at Chilling Activism in Utah Overturned in Animal Legal Defense Fund v. Herbert.}

In 2012, a Utah state legislator introduced a bill he declared "motivated by a trend nationally of some propaganda groups... with a stated objective of undoing animal agriculture in the U.S." ${ }^{106}$ Successful undercover investigations in California and Iowa resulted in both intense public backlash and legislative action, scaring the agriculture industry across the U.S. ${ }^{107}$ Utah's ag-gag bill passed, containing four key provisions: the criminalization of obtaining "access to an agricultural operation under false pretenses," and bans on different filming methods - bugging, filming after applying for a job with the intent to film, and filming while trespassing. ${ }^{108}$

In Animal Legal Defense Fund v. Herbert, a federal district court in Utah concluded that all three plaintiffs had standing under the "chilling effects" standard ${ }^{109}$ and granted their motion for summary judgment. ${ }^{110}$ The court found the First Amendment applied to the ag-gag law in question because the First Amendment protects lies that "do not cause legally cognizable harm," and "at least some of the lies criminalized by the [statute] retain First Amendment protection." 111 Next, restrictions on the creation of speech "are treated similarly to restrictions on speech itself" because "the consensus among courts is that the act of recording is protectable First Amendment speech." 112 The court also found both the lying and recording provisions restricted content-based speech, because both provisions require a prosecutor examine either the words or the video footage itself. ${ }^{113}$

Therefore, the court found strict scrutiny applied, and the ag-gag law failed to withstand strict scrutiny. ${ }^{114}$ The state argued the law protected animals from diseases brought by outsiders, protected workers from exposure to animal diseases, and protected both animals and workers from injuries at the hands of unqualified workers. ${ }^{115}$ Unconvinced, the court referred to the legislative history and determined "it

concrete and particularized invasion of a legally protected interest"; see also Id., quoting Whitmore v. Arkansas, 495 U.S. 149 , 155 (U.S. 1990) and Susan B. Anthony List v. Driehaus, 134 S. Ct. 2334, 2341 (U.S. 2014), requiring the threatened injury be "concrete in both a qualitative and temporal sense," and "certainly impending" or at least a "substantial risk' the harm will occur".

${ }^{98} I d$., at $384,386$.

${ }^{99} \mathrm{Id}$. at 378 .

${ }^{100}$ Id. at 385-86.

${ }^{101}$ PETA, 2018 WL 2714684 at $\bullet 1$.

102 Id. at *3.

${ }^{103} I d$. at $* 4$.

${ }^{104} \mathrm{Id}$. at *4, quoting Cooksey v. Futrell, 721 F.3d 226, 229 (4th Cir. 2013).

${ }^{105} I d$. at $* 6$.

${ }^{106}$ Animal Legal Def. Fund v. Herbert, 263 F. Supp.3d 1193, 1198 (D. Utah 2017).

${ }^{107} \mathrm{Id}$.

${ }^{108}$ Id.; See UTAH CODE ANN. § 76-6-112 (2017).

109 The "chilling effect" standard refers to the Tenth Circuit Court's three part test to assess standing for plaintiffs who allege injury based on a "chilling effect" of a restriction. Animal Legal Def. Fund v. Herbert, 263 F. Supp.3d 1193, 1199 (D. Utah 2017) quoting Initiative \& Referendum Inst. v. Walker, 450 F.3d 1082, 1089-88 (10th Cir. 2006)). The court also found one plaintiff had standing because Utah had prosecuted her under the ag-gag law before later dropping the case. Herbert, 263 F. Supp.3d at 1200.

${ }^{110}$ Herbert, 263 F. Supp.3d at 1213.

${ }^{111} I d$. at $1202-03$.

112 Id. at 1208 .

${ }^{113}$ Herbert, 263 F. Supp.3d at 1210-11.

${ }^{114} \mathrm{Id}$. at 1213 .

${ }^{115} \mathrm{Id}$. at 1211 .

152 Derecho Animal. Forum of Animal Law Studies, vol. 10/1 
is not clear that these were the actual reasons motivating the [law]." ${ }^{116}$ Even if the state's rationale were legitimate, the state failed to provide proper evidence; narrowly tailored restrictions must be "actually necessary" and neither over nor under inclusive to achieve the state interest. ${ }^{117}$ Instead, the court found the restriction "perfectly tailored" to prevent undercover investigators from sharing animal abuses with the public. ${ }^{118}$ Accordingly the court found Utah's ag-gag law unconstitutional. ${ }^{119}$ The Utah Attorney General's Office has stated it will not appeal the decision. ${ }^{120}$

\section{c. Protecting Free Speech but not Misrepresentation in Animal Legal Defense Fund v. Otter and Animal Legal Defense v. Wasden.}

In 2014, Mercy for Animals captured a video of workers dragging a sick cow by its neck with a chain across an Idaho dairy facility. ${ }^{121}$ Negative publicity ensued, and the Idaho Dairymen's Association sponsored a bill to create a new crime of "interference with agricultural production." ${ }^{122}$ Some legislators commenting on the bill labeled undercover activists as "extremist groups" and "terrorists," while others supported the bill because they believed in a "need to protect members of the dairy industry from undercover investigators." ${ }^{123}$ The bill criminalized the act of obtaining employment in an agricultural facility by misrepresentation, as well as making video recordings of conduct in production facilities. ${ }^{124}$

In Animal Legal Defense Fund v. Otter, a federal district court found that Idaho Code $\S 18-7042$ "seeks to limit and punish those who speak out" about animal agriculture issues; the statute suppressed speech involving public interest topics. ${ }^{25}$ The too-broad statute created "a particularly serious threat to whistleblowers" free speech rights" and "criminalize[d] recordings even when made by a person who is otherwise lawfully permitted to be there." 126 Because content-based speech restrictions are unconstitutional "unless they are narrowly tailored to a compelling state interest," and the court failed to find proper narrow tailoring, the court declared Idaho Code section 18-7042 unconstitutional. ${ }^{127}$

In Animal Legal Defense Fund v. Wasden, the Ninth Circuit Court of Appeals reversed the lower court's decision in-part. The court held that while audio and video recording of facility operations and misrepresentation to enter a facility are protected speech under the First Amendment, misrepresentation to obtain records or employment are not so protected. ${ }^{128}$ The court upheld the permanent injunction against the overly broad entry by misrepresentation provision which criminalized innocent behavior and targeted specifically "falsity and nothing more." 129 The court also affirmed the unconstitutionality of the recording provision, defining it as a "classic example of a content-based restriction" under the strict scrutiny test. ${ }^{130}$ Oppositely, the court found the misrepresentation to obtain records targeted behavior "long prohibited in Idaho," 131 and the provision on employment only criminalized misrepresentation to obtain employment by individuals with intent to cause injury to the facility. ${ }^{132}$ The court concluded that neither of these two misrepresentation provisions targeted behavior protected by the First Amendment. ${ }^{133}$

\section{CHALLENGES TO SPEECH AND EXPRESSION RESTRICTIONS IN EUROPE}

Animals used in agriculture in Europe benefit from more widespread and uniform anti-cruelty measures than animals in the U.S. For example, veal crates, pregnant sow crates, and laying hen battery crates - often considered the most cruel forms of confinement — are all illegal in the European Union. ${ }^{134}$ On

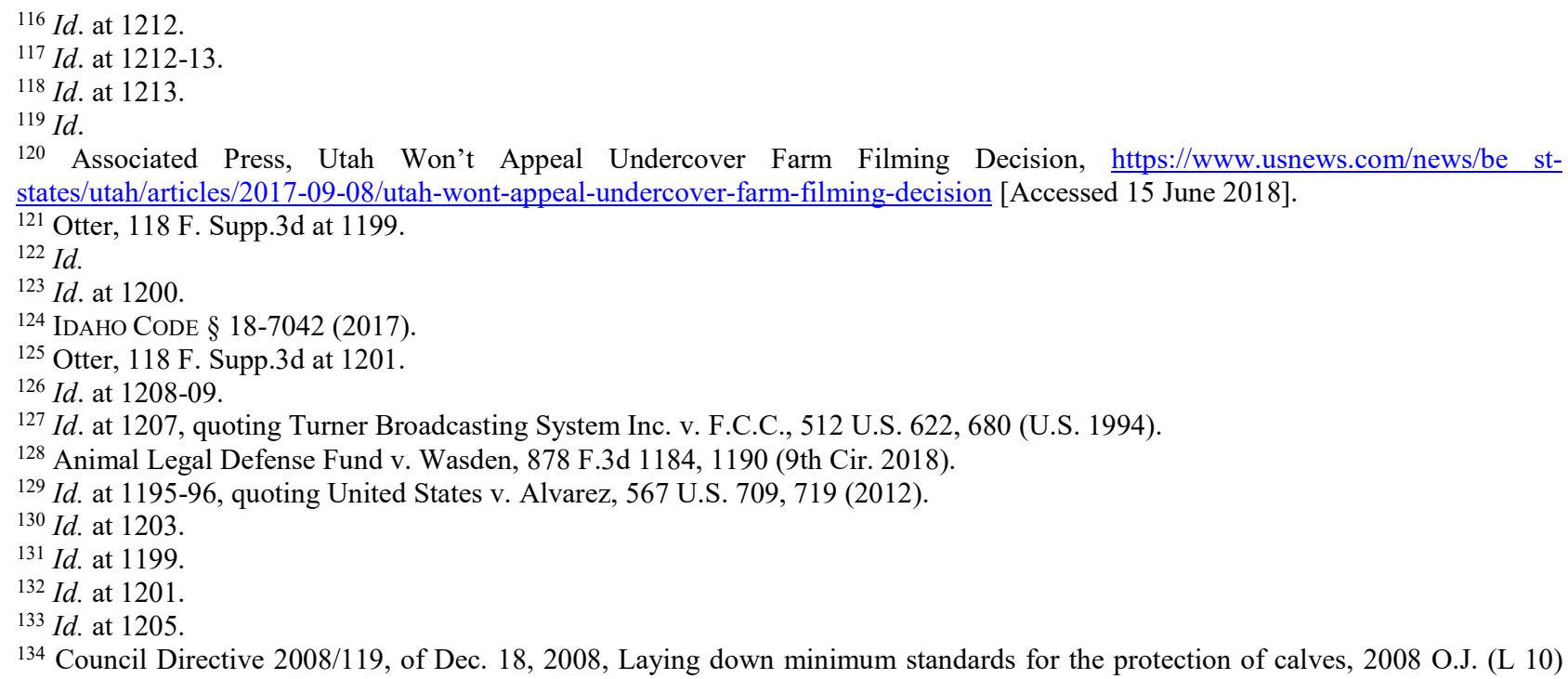


the other hand, free speech restrictions found in many European countries exceed those in the U.S. These restrictions include criminal liability for defamation in Germany, ${ }^{135}$ a prohibition on paid political advertising in the UK, ${ }^{136}$ and a federal constitutional provision Switzerland guaranteeing the impartiality of radio and television together with a legislative prohibition on religious and political advertisements. ${ }^{137}$

\section{a. Animal Welfare Commercials are not Political: Free Speech v. Political Speech in VgT Verein Gegen Tierfabriken v. Switzerland.}

In Vgt Verein Gegen Tierfabriken v. Switzerland, an animal welfare association claimed Switzerland violated its freedom of expression under Article 10 of the Convention. ${ }^{138}$ The association claimed Switzerland's responsibility for a broadcast company's refusal to air their pro-animal welfare commercial on national television. ${ }^{139}$ Switzerland argued the Swiss legal restriction on political advertising qualified as an exception under Article $10 \S 2$ of the Convention because it protected the rights of others. ${ }^{140}$ The Court found an Article 10 violation. ${ }^{141}$

The Swiss Federal Constitution guarantees the impartiality of radio and television, and the autonomy of programme creation, ${ }^{142}$ while the Federal Radio and Television Act prohibited political advertising and required advertising "be clearly separated from the rest of the programme and shall be clearly recognizable as such." 143 The company responsible for Swiss national television advertising found the applicant's commercial had a "clear political character" and rejected it. ${ }^{144}$ Switzerland agreed, arguing their legal restriction on political advertising qualified as an exception under Article $10 \S 2$ of the Convention because it protected the rights of others. ${ }^{145}$ The Swiss Federal Court upheld the rejection. ${ }^{146}$

The commercial in question contained two scenes. The first scene, against a backdrop of soft music, showed a sow building a shelter for her piglets in a forest. ${ }^{147}$ The second scene showed a crowded pig farm while a voice in the background compared the farm to a concentration camp and warned consumers about over-medicated meat. ${ }^{148}$ The commercial urged viewers to reduce meat "for the sake of their health, the animals, and the environment." 149

The European Court of Human Rights ultimately found in favor of the activists. First, the Court held Switzerland responsible for the alleged violation because Swiss law effectively prohibited political speech, ${ }^{150}$ and the commercial qualified political because it "reflected controversial opinions pertaining to modern society." 151 Switzerland's responsibility established, the Company's refusal to broadcast the commercial qualified as an "interference by public authority." 152 The Court found this "prescribed by law" interference satisfied a legitimate government goal under Article $10 \S 2$ of the Convention, namely

(EC); Council Directive 2008/120, of Dec. 18, 2008 Laying down minimum standards for the protection of pigs, 2008 O.J. (L 47) (EC); Council Directive 1999/74, of July 19, 1999, Laying down minimum standards for the protection of laying hens, 1999 O.J. (L 203) (EC).

${ }^{135}$ See Case of Tierbefreier E.V. v. Germany, No. 45192/09, Eur. Ct. H.R. I 30 (Jan. 16, 2014); see Strafgesetzbuch [German Criminal Code] § 187.

${ }^{136}$ See Case of Animal Def. Int'1 v. The United Kingdom, No. 48876/08, Eur. Ct. H.R. ๆ 3 (Apr. 11, 2013)' see Communications Act 2003 (U.K.).

137 See Vgt Verein Gegen Tierfabriken, Eur. Ct. H.R. ๆ甲 24, 28, 30; see also Schweizerisches Bundesgesetz über Radio und Fernsehen [Federal Act on Radio and Television] Mar. 24, 2006 (Switz.).

${ }^{138}$ Vgt Verein Gegen Tierfabriken, Eur. Ct. H.R. $\uparrow 3$.

${ }^{139} \mathrm{Id}$. $₫ 8$.

${ }^{140} I d$. 90 ; see European Convention on Human Rights, art. $10 \S 2$.

${ }^{141} I d$ Id 979.

${ }^{142}$ Vgt Verein Gegen Tierfabriken, Eur. Ct. H.R. I 24; Bundesverfassung der Schweizerischen Eidgenossenschaft [Switzerland Federal Constitution] art. 93.

${ }^{143}$ Id. ๆ 28; See Schweizerisches Bundesgesetz über Radio und Fernsehen [Federal Act on Radio and Television] Mar. 24, 2006 (Switz.). The Swiss Federal Act on Radio and Television 784.40 was amended in 2006. This case was decided June 28, 2001 and involved a previous version. For section 18(5) of the Swiss Federal Act on Radio and Television as referenced by the case, see Vgt Verein Gegen Tierfabriken, Eur. Ct. H.R. $\mid 21$.

${ }^{144}$ Vgt Verein Gegen Tierfabriken, Eur. Ct. H.R. \$ף 11-12.

${ }^{145} I d$. 60; See European Convention on Human Rights, art. $10 \S 2$.

${ }^{146} I d$. 121 (reasoning the restriction prevented "financially powerful groups from obtaining a competitive political advantage").

${ }^{147} I d$. $\uparrow 10$.

${ }^{148} I d$.

${ }^{149} \mathrm{Id}$.

${ }^{150}$ Vgt Verein Gegen Tierfabriken, Eur. Ct. H.R. qศ 44, 45, 47, also finding the Convention requires "each Contracting State '...secure to everyone within [its] jurisdiction the rights and freedoms defined in... [the] Convention." As a result, the Court concluded a State's responsibility "may then be engaged as a result of not observing its obligation to enact domestic legislation".

${ }^{151} I d$. 150.

${ }^{152} I d$. 48.

154 Derecho Animal. Forum of Animal Law Studies, vol. 10/1 
protecting the rights of others. ${ }^{153}$

The restriction ultimately failed the Court's proportionality test. The Court found the association was neither the type of politically powerful organization against whom Switzerland sought to protect her citizens, nor capable of engaging in public debate without access to television. ${ }^{154}$ Switzerland had failed to provide relevant or sufficient reasons to justify the restriction in this applicant's case. ${ }^{155}$ As a result, Switzerland violated Article $10 \S 2$, and the Court afforded the applicant organization just satisfaction of 20,000 Swiss Francs. ${ }^{156}$

\section{b. When Animal Welfare Ad Campaigns Become Political: Molding Democratic Visions Through Political Advertisement Restrictions in Case of Animal Defenders International v. The United Kingdom.}

In Case of Animal Defenders International v. The United Kingdom, Animal Defenders International ("NGO") alleged the UK violated Article 10 after the British Broadcast Advertising Clearance Centre ("Centre") found the NGO's advertisement political and accordingly prohibited its broadcast. ${ }^{157}$ The applicant NGO organized campaigns against the use of animals for science and leisure. ${ }^{158}$ These campaigns sought to change the law and influence UK parliamentary opinion and public policy; one such campaign titled "my mate's a primate," involved the advertisement at issue. ${ }^{159}$ The advertisement featured a girl in chains emerging from a cage, while messages about the mental capacity and genetic makeup of chimps appeared in writing on a blank screen. ${ }^{160}$ The advertisement ended urging viewers help stop this use of animals; at the end, the chimp replaced the girl in chains in the cage. ${ }^{161}$

Section of 321(2) of the UK Communications Act 2003 prohibits advertisements which are "inserted by or on behalf of a body whose objects are wholly or mainly of a political nature" or "directed towards a political end." 162 The same act also imposes "the statutory obligation of impartiality on all broadcasters" in the UK. ${ }^{163}$ The Centre argued the UK's legal prohibition on paid political advertising required the advertisement's rejection. ${ }^{164}$ The UK argued Parliament prohibited the broadcast of paid political advertisement to protect the impartiality of the democratic process qualified as an exception because it was "necessary in a democratic society." 165 The British High Court differentiated this case from the Court's decision in VgT Verein Gegen Tierfabriken, holding it had "turned on its facts" and did not apply to the case at hand. ${ }^{166}$

The Court found the restriction resulted from "the culmination of an exceptional examination by parliamentary bodies," all of which "found the prohibition to have been a necessary interference." 167 The Court also found the restriction proportionate and "specifically circumscribed to address the precise risk of distortion the State sought to avoid." 168 The prohibition, part of a greater regulatory framework involving the public interest, resulted from "the culmination of an exceptional examination by parliamentary bodies." 169 Thus, Court found prohibition a necessary interference - the UK had not violated Article $10 .{ }^{170}$

\section{c. Protecting Reputations in Tierbefreier v. Germany: When Freedom of Expression Threatens to Harm a Company's Image.}

In Tierbefreier E.V. v. Germany, applicants applied for a civil injunction against the distribution of

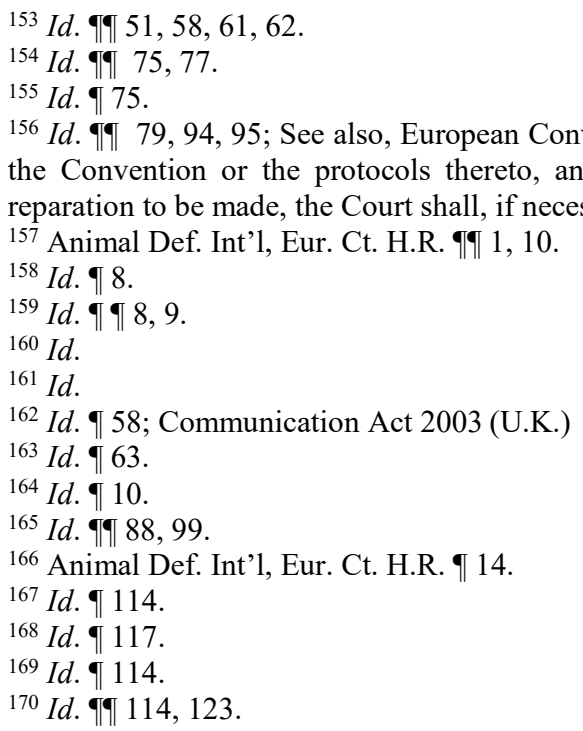


video footage from an undercover animal research facility investigation violated their freedom of expression under Article 10 of the Convention. ${ }^{171}$ One of the applicants, a journalist, began work a research facility that bred monkeys and conducted animal experiments. ${ }^{172}$ The journalist secretly filmed animals inside the facility, collecting over forty hours of footage. ${ }^{173}$ The journalist made one short film with the footage, criticizing the company's treatment of animals, and multiple German broadcast companies aired this film. ${ }^{174}$ The applicants used much of the same footage to make a second, longer film; this film claimed the company "systematically flouted" applicable laws and alleged staff treated animals harshly and cruelly. ${ }^{175}$

Under Article 5 of section 1 of the German Constitution, every person has the right to "freely express and disseminate his opinions." ${ }^{176}$ The same section allows general laws to limit these rights to protect young persons or personal honor. ${ }^{177}$ Section $823(1)$ of the German Civil Code holds liable any person who "intentionally or negligently, unlawfully injures the life, body, health, freedom, property or another right of another person." 178 Additionally, Section 187 of the German Criminal Code punishes defamation, which includes disseminating "a fact related to another person which may defame him or negatively affect public opinion about him" with imprisonment or a fine. ${ }^{179}$ Finally, German civil law allows people whose personality rights are at risk "to compel that other person to refrain from performing the impugned action." 180

In this case, after the activists collected the secret footage, a German company contracted under the Animal Welfare Act to conduct an animal research applied for a civil injunction to prevent the applicants from disseminating film footage taken in their facility. ${ }^{181}$ Germany justified these restrictions under Article 10 as necessary to protect the rights of others and to prevent of disorder or crime. ${ }^{182}$ The German Court of Appeals found the footage "could only be published if the information's importance for the public clearly outweighed the disadvantages suffered by the injured party." 183 Because the applicants obtained the footage unlawfully and interfered with the company's right not to be spied on, the court upheld the injunction. ${ }^{184}$

The European Court of Human Rights first acknowledged that both parties accepted the that civil injunction interfered with the applicants' freedom of expression. Next, the Court concluded that the civil injunction against the footage qualified as an interference "prescribed by law." 185 This interference also pursued a legitimate aim under section 2 of Article 10: "the protection of the reputation or rights of others." ${ }^{186}$ The Court acknowledged the need to provide special protection to questions of public interest, ${ }^{187}$ but nevertheless found compelling the applicants' use of unfair means in their so-called "battle of ideas" against the company. ${ }^{188}$ Ultimately, the Court found the German Court of Appeals "struck a fair balance" between the applicant's freedom of expression and protecting the Germany company's reputation. ${ }^{189}$ Besides, as the German courts had already stated, the applicants were free to criticize animal experiments in other ways. ${ }^{190}$ The Court found Germany had not violated Article 10 under the Convention. ${ }^{191}$

\section{ANALYSIS}

\section{FOUNDATION OF A DEMOCRATIC SOCIETY: SPEECH IS SPECIAL}

The right to express opinions and speak freely without government intervention is a critical component of a functioning democracy. Censorship allows governments to restrict information, propagate a

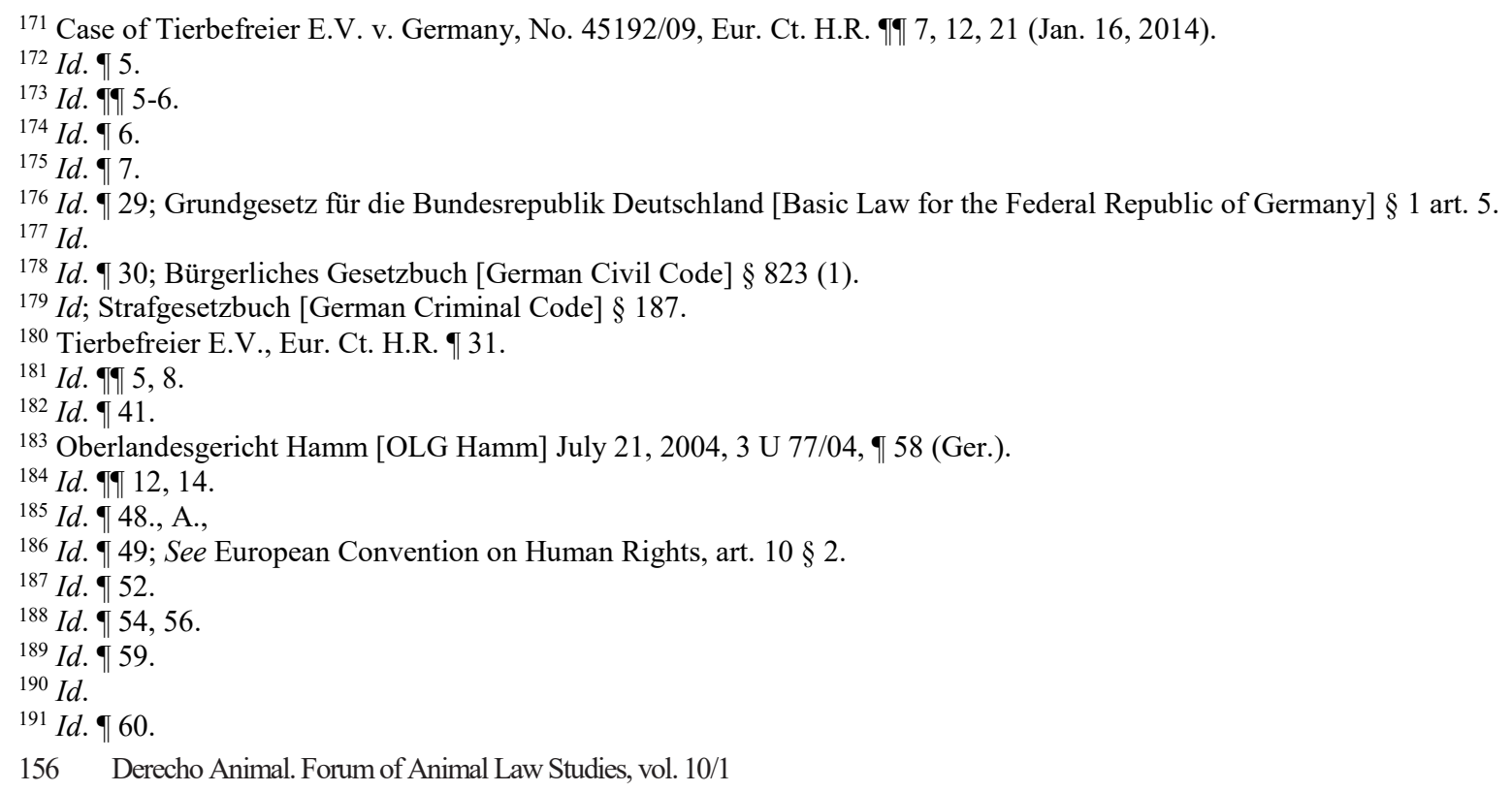


tainted agenda, and misinform the masses. Many revolutionary constitutions abolished censorship and extended free speech and expression rights to the media; this suggests free speech encompasses "the right of all citizens to be informed." 192

The European Court of Human Rights labeled the freedom of expression under Article 10 as "one of the essential foundations of a democratic society." 193 Justice Brandeis of the U.S. Supreme Court argued the "safety lies in the opportunity to discuss freely supposed grievances and proposed remedies." 194 Brandeis' solution involved "more speech, not enforced silence." 195 Unsurprisingly, free speech in the U.S. under the First Amendment is popularly, although incorrectly, viewed in absolutist terms: free speech seemingly reigns above all else. ${ }^{196}$

Surprisingly, republican state legislators in Idaho, North Carolina, and Utah, popularly known for touting small government ideals, passed sweeping legislation to restrict speech-lying and video recording - in animal production facilities. In these cases, private property and food industry interests easily trumped free speech concerns, at least according to state legislators. Only in court, when out-of-state animal welfare organizations challenged these restrictions, did free speech concerns take a central role in the debate. In New York City, investigative reports and op-eds sounded the alarm on states' attempts to stifle speech, warning these ag-gag laws violated free speech rights and threatened transparency in the animal agricultural industry. ${ }^{197}$ The welfare of animals mattered now that Americans' cherished free speech rights were threatened.

In Europe, popular belief assumes Europeans accept greater free speech restrictions. The European Convention on Human Rights ("Convention") itself explicitly allows states to restrict expression, despite the central role the freedom of expression plays in protecting other Convention rights. ${ }^{198}$ Restrictions are allowed so long as they are clearly prescribed by law, necessary in a democratic society, and satisfy one of many specific objectives, including public safety, the protection of the rights of others, or national security ${ }^{199}$ As a result, the Court upheld Germany's injunction against a video that threatened the personal honor of a research company and the UK's prohibition on paid political advertising, while rejecting Switzerland's less convincingly reasoned, but very similar prohibition on paid political advertisements. ${ }^{200}$

Procedural, historical, and contextual differences between Europe and the United States help explain the differences between freedom of speech and expression challenges by animal activists at home and abroad.

\section{FREEDOM OF EXPRESSION VERSUS FREE SPEECH CHALLENGES}

\section{a. Procedural Differences Between the European Court of Human Rights and U.S. District Courts.}

Several procedural aspects differentiate "freedom of speech" challenges in the U.S. from the "right to freedom of expression" jurisprudence of the European Court of Human Rights ("European Court"). First, once jurisdiction is established, U.S. federal district courts examine ag-gag laws as first instance courts. The European Court, however, may only hear cases once the applicant has exhausted all domestic remedies in the state which allegedly violated their rights. ${ }^{201}$ This allows member states the chance to remedy an alleged breach, reaffirming the states' role as part of the "machinery of protection" to guard human rights under the Convention. ${ }^{202}$

Both systems lack jurisdiction to review a national law upon request. In the United States, plaintiffs need standing, either an actual injury or threat of injury, and in Europe persons who bring applications must have been "directly affected by an alleged violation" and may not "complain generally of certain legislation." ${ }^{203}$ If admissibility is established, the U.S. courts use a categorical approach ${ }^{204}$ to assess free

\footnotetext{
${ }^{192}$ DORSEN, N. et al., Comparative Constitutionalism: Cases and Materials (Thompson Reuters 2nd ed. 2010) 847.

${ }^{193}$ RAINEY, B. et. al., supra note 9, at 483, quoting Handyside v. UK, No. 5493/72, 1 EHRR 737948 (Dec 7 1976).

${ }^{194}$ DORSEN, N. et al., supra note 192, at 851, quoting Whitney v. CA, 274 U.S. 357, 375 (U.S. 1927).

$195 \mathrm{Id}$. at 852 .

${ }^{196} \mathrm{Id}$. at 854 .

197 See GENOWAYS, supra note 30; see New York Times Editorial Board, supra note 34.

198 RAINEY, B. et. al., supra note 9, at 486.

${ }^{199}$ PANNICK, D., Article 10 of the European Convention on Human Rights, 4 K.C.L.J. 44-45 (1993-94).

200 RAINEY, B. et. al., supra note 9, at 512 (Importantly, the Court's distinction between Tierfabriken and Animal Defenders International remains contested. The dissent in Animal Defenders International saw no difference between the prohibition on political advertisement in the UK and "identical prohibition" in Switzerland).

${ }^{201}$ Convention for the Protection of Human Rights and Fundamental Freedoms (European Convention on Human Rights) art. 35, Nov. 4, 1950 (entered into force Sept. 3, 1953).

202 RAINEY, B. et. al., supra note 9, at 34.

${ }^{203}$ PETA, 259 F. Supp.3d at 374; RAINEY, B. et. al., supra note 9, at 29, explaining Art 34, allowing "any person, non-government
} 
speech restrictions, while the European Court assesses the proportionality of government interests against free expression rights.

\section{b. Historical Background and Current Application: U.S. Categorical Approach Versus Proportionality in Europe.}

The proportionality principle originated in Germany, under Prussian administrative court judges, as a means to limit government action to "only those measures that were necessary for achieving its legitimate goals." 205 With individual rights not explicitly protected by a constitution, a formalist means and ends analysis introduced the idea of rights into German law to protect "natural rights," while making the administration of law more efficient and rigorous. ${ }^{206}$ Historical struggles, including social reform sought through the French Revolution and the atrocities of World War II led to a conception of positive rights, explicitly spelled out in the Convention, which require government action to protect. ${ }^{207}$

On the other hand, the U.S. Bill of Rights protected rights by first limiting the federal government, and later the states. ${ }^{208}$ Thus, the Fourteenth Amendment protects speech from unconstitutional state restrictions, ${ }^{209}$ placing the courts in a defensive role of retroactively overturning unconstitutional state speech restrictions. While both the Convention and U.S. Constitution can limit government lawmaking, the European Court and U.S. federal district courts view their roles in remedying violations differently.

In the U.S., a categorical approach to free speech restrictions developed in a system with strong textual rights protections. Over ninety years of free speech jurisprudence and a distrust of judicial discretion led the U.S. Supreme Court to create many rules, tests, and presumptions to assess speech restrictions. ${ }^{210}$ This categorical approach applies a sort of "wholesale balancing at the level of defining general categories," where the court balances the free speech right against other involved rights depending on the category of protected speech. ${ }^{211}$ In Utah for example, the court in Herbert found the government's rationale insufficient under a strict scrutiny test, after finding a content-based restriction. ${ }^{212}$ This approach allows for government limits on certain categories of speech for public interest reasons, if proper justification is provided. ${ }^{213}$

The European Court applies the principle of proportionality to ensure a member state's restriction is reasonable. This requires the means by which a state hopes to achieve an objective be proportional to the means used to achieve it. In Europe, this ensures rights remain protected despite failures by member states to pass proper domestic legal protections, whereas the balancing test in the U.S. limits a possibly limitless reading of the First Amendment. ${ }^{214}$

The history of Germany's proportionality principle, however, does not provide a complete picture of the European Court's balancing exercise and proportionality assessment. The framework of the Convention gives member states the responsibility to protect individual rights. ${ }^{215}$ The European Court simply examines whether a right is involved, and if so, balances the government's interest against the protected right as defined in the Convention. ${ }^{216}$ Therefore, when applying a margin of appreciation, the European Court considers local conditions and circumstances. ${ }^{217}$ As a result, considerations may vary greatly, depending on the purpose of the member state's restriction and the type of expression being restricted. ${ }^{218}$

organization, or group of individuals claiming to be the victim of a violation" includes both corporate or unincorporated bodies.

${ }^{204}$ DORSEN, N. et. al., supra note 192, at 855.

${ }^{205}$ COHEN, M. E., PORAT, I., American Balancing and German Proportionality: The Historical Origins, International Journal of Constitutional Law, 8/2 (2010) 272.

${ }^{206} I d$. at $273,276$.

207 See HALBERSTAM, D., supra note 21, at 167, 171.

${ }^{208}$ See Gitlow, 268 U.S. at 666 (U.S. 1925), incorporating the First Amendment against the states, the court found the First Amendment "among the fundamental personal rights and "liberties" protected by the due process clause of the Fourteenth Amendment from impairment by the States".

${ }^{209}$ McCLOSKEY R. G. (ed.), Essays in Constitutional Law (Knopf 1957) 275.

${ }^{210}$ HALBERSTAM, D., supra note 21, at 168.

${ }^{211} \mathrm{Id}$. at 177 .

${ }^{212}$ Herbert, 263 F. Supp.3d at 1212.

${ }^{213}$ COHEN, M. E., PORAT, I., supra note 205, at 284.

${ }^{214} \mathrm{Id}$. at 266.

${ }^{215}$ RAINEY, B. et. al., supra note 9, at 486.

${ }^{216}$ HALBERSTAM, D., supra note 21 , at 168.

217 SAUL, M., The European Court of Human Rights Margin of Appreciation and the Process of National Parliaments, Human Rights Law Review, 15/4 (2015) 749; see also Case of Vgt Verein Gegen Tierfabriken v. Switzerland, No. 24699/94, Eur. Ct. H.R. 9 69 (June 28, 2001).

${ }^{218}$ RAINEY, B. et. al., supra note 9, at 486.

158 Derecho Animal. Forum of Animal Law Studies, vol. 10/1 


\section{c. How Context Shapes Outcomes, Despite Similar Restrictions, at the European Court of Human Rights and U.S. Federal District Courts.}

Both U.S. Federal District Courts and the European Court place great weight on context, examining closely legislative intent and the social/political power of the involved parties. Of the three cases examined, the European Court only found one violation. In Vgt Verein Gegen Tierfabriken, Switzerland failed to show its restriction proportionately achieved political neutrality objectives. Curiously, in Animal Defenders, the European court unjustifiably upheld a very similar UK regulation after failing to focus on the individual facts of the case and yielding instead to the state's general reasoning for the ban. Rather than question whether calls for improved animal welfare regulations qualified as political, the Court assessed the general rationale for the ban, easily accepting the UK's labeling of the commercial as political and subsequent right to regulate. A thoughtful legislature, properly researched ban, and lack of consensus in other European countries swayed the Court; the ban was upheld.

In Idaho and Utah, the context in which the state restriction passed also played a decisive role. The district court judges relied heavily on legislators' motivations for passing the ag-gag laws, and used their own statements against them to disprove the government's post-hoc rationale for the laws. These judges in both Idaho and Utah pointed to the detrimental effects of previous undercover investigations, including lost profits, poor public image, and public outcry against the animal facility operators. Neither judge pretended as though the ag-gag laws suddenly appeared to enhance safety and hygiene measures. Because neither Utah nor Idaho could convince the court of their claimed intentions, the true motive-ending undercover investigations - made for relatively straightforward First Amendment violations. In Idaho, the appellate court found the federal district court had even gone too far; in North Carolina, the appellate court found the actual purpose of the ag-gag law played too small a role in the federal district court's analysis.

The social and political power of the parties also played a role in both the U.S. and Europe. In Tierbefreier, the opinion reads as though the European Court viewed the issue through the lens of a personal dispute between two parties, rather than a public debate involving information sharing and transparency. For example, the European Court outlined in detail the domestic courts' rationale in upholding the civil injunction against the short film's dissemination. Rather than discussing the need for open public debate, court characterizes the case as an intellectual battle of ideas. As a result, German defamation laws applied. Similarly, in the U.S. in PETA, the federal district court in North Carolina analyzed the issue from the perspective of two private parties, finding the law simply created a private right of action between two parties.

In each case examined in this paper, financial resources and economic power also mattered. The European Court ruled against a large private Swiss broadcast company with government delegated power, and the U.S. district courts in Utah and Idaho sided against the powerful agricultural lobby and state government legislatures working in concert. In comparison, in North Carolina, the court initially found the eight national and well-funded non-profit organizations' uninjured by the speech restriction in question, while the European Court viewed the private German research company on equal footing as the animal welfare organization.

Intended effects also matter. In the UK, the Animal Defenders International created the commercial as a part of its campaign to change legislation and public policy regarding the use of animals. In Germany, the sensationalist accusations against the animal experiment company were found to increase the chances of criminality against the company. Alternatively, in Switzerland, Utah, and Idaho, the applicants/plaintiffs merely sought to educate the public about animal abuses, and the courts accordingly found the effects of the speech restriction themselves more compelling.

\section{CONCLUSION}

The European Court of Human Rights recognizes its powerful role and treads cautiously in full recognition of member states' responsibility to protect legitimate interests through democratically created regulations. As a result, the European Court questionably accepted the UK's rationale, despite rejecting Switzerland's similar ban, because the UK properly and proportionately regulated a legitimate interest. Should this holding create cause for concern in the United States? The current, hastily written and overbroad ag-gag laws make for simple cases, but will U.S. courts be able to rule against future, more subtly and strategically crafted ag-gag laws?

Under Professor Halberstam's conception of U.S. rights, likely not. Regardless of how the current U.S. approach to free speech jurisprudence is labeled, the complex combination of categorical analysis, 
balancing considerations, and examining government motivations provides a powerful buffer against unconstitutional infringements when the government acts for bad reason. ${ }^{219}$ Created against the historical context of newfound independence and drafted as a negative right restricting the government, the First Amendment should be able to withstand even carefully crafted legislation. Any future ag-gag laws, passed under the familiar guise of public health and safety, will have been created for bad reasons - to silence speech and reduce transparency in the animal agricultural industry. The tried and tested First Amendment will continue to withstand attempts, made for bad reasons, to quell free speech. As a result, animal activists can continue to rely on the safeguards provided by the First Amendment to protect against future attempts by state legislators to suppress whistleblower activities in animal agriculture operations. 